\title{
Parental Attitude towards Supported Competitive Employment for Their Hearing Impaired Children
}

\author{
Dr Sreeja S \\ Asst.Professor, Avila College of Education, Edacochin
}

\begin{abstract}
The efforts to make every disabled persons independent, economically through programme of education, habilitation and rehabilitation was recognized. Supported competitive employment is a vocational alternative which would improve the quality of the life of hearing impaired person. The present investigation is meant to assess parental attitude towards supported competitive employment for their hearing impaired children. Survey method was adopted for the conduct of the study. The sample consisted of 120 parents selected from eight revenue districts of Kerala, viz - Thiruvananthapuram, Kollam, Kottayam, Ernakulam, Thrissur, Pathanamthitta, Idukki and Kozhikode. The sample was selected using random sampling technique. The selected sample represented almost all the sections prevailing in the society. High, middle and low income groups were randomly selected to get a better vision and deeper insight into the nature of what it is dealing with. To collect the data required for the study, an attitude scale prepared and validated by the investigator was used. To study the parental attitude towards the employability of their hearing impaired children, the investigator administered an attitude scale to a sample of 120 parents of hearing impaired students randomly selected from eight Districts in Kerala. The attitude scale consisted of twenty five items related to three areas such as parent's attitude on the employability, placing children in existing jobs and the extent of support parents are willing to provide. The first section consists of five statements about the parents attitude on the employability, second section consists of four statements with twelve sub items regarding parents attitude in placing their hearing impaired children in existing jobs and the third section consists of four statements about the extent of support parents are willing to provide their children. The attitude scale includes the responses, strongly agree, agree, undecided, disagree and strongly disagree. The treatment of data was carried out employing percentage analysis. The result revealed that parental communities (99\%) as a whole have strong agreement towards supported competitive employment for their hearing impaired children.
\end{abstract}

\section{Background Of The Study}

Hearing loss in children is a silent hidden handicap. One child in among thousand is born with profound deafness. Deafness in children is a serious concern because it interferes with the development of language that which selects humans apart from all other things. Every interventions with hearing impaired children results in improved language development, increased academic success and increased life time earnings. Parents are in the best position to identify their child's hearing difficulties. The awareness of parents regarding the danger signals and of the sources of help that are available is necessary for better guidance. The importance of parental involvement is the employment process of their hearing impaired is crucial to the child's success in future. There are no specific guidelines that can be followed when dealing with parents.

The efforts to make every disabled persons independent, economically through programme of education, habilitation and rehabilitation was recognized. Supported competitive employment is a vocational alternative which would improve the quality of the life of hearing impaired person. These individuals should get proper training and opportunities and every attempt should be made to improve the employment option in the future. When disability reduces the capacity to earn or prevents jobs being available, it is a loss to the national exchequer. It can place heavy burden on the person himself, his care takers and economic performances of the care givers and ultimately the society. The situation demands that each individual must contribute to the economic growth including the disabled, who has come to be recognized as a human resource. In order to introduce this educational alternative, it is essential to find out the attitude of parents towards this. Any attempt for the benefit of disabled people should be stimulated and supported by their family members, especially parents. Therefore, it seems very essential to conduct a study to find out the attitude of parents to supported competitive employment for their hearing impaired children.

\section{Objectives}

1. To find out the parental attitude on the employability of their hearing impaired children.

2. To study parent's attitude on placing children in the existing jobs in the community.

3. To find out the extent of support parents are willing to provide in child's employment. 


\section{Methodology In Brief}

The present investigation is meant to assess parental attitude towards supported competitive employment for their hearing impaired children. Survey method was adopted for the conduct of the study. The sample consisted of 120 parents selected from eight revenue districts of Kerala, viz - Thiruvananthapuram, Kollam, Kottayam, Ernakulam, Thrissur, Pathanamthitta, Idukki and Kozhikode. The sample was selected using random sampling technique. The selected sample represented almost all the sections prevailing in the society.

High, middle and low income groups were randomly selected to get a better vision and deeper insight into the nature of what it is dealing with. To collect the data required for the study, an attitude scale prepared and validated by the investigator was used. To study the parental attitude towards the employability of their hearing impaired children, the investigator administered an attitude scale to a sample of 120 parents of hearing impaired students randomly selected from eight Districts in Kerala. The attitude scale consisted of twenty five items related to three areas such as parent's attitude on the employability, placing children in existing jobs and the extent of support parents are willing to provide. The first section consists of five statements about the parents attitude on the employability, second section consists of four statements with twelve sub items regarding parents attitude in placing their hearing impaired children in existing jobs and the third section consists of four statements about the extent of support parents are willing to provide their children. The attitude scale includes the responses, strongly agree, agree, undecided, disagree and strongly disagree. The treatment of data was carried out employing percentage analysis.

\section{Analysis}

The details of the analysis are given in table no.1, 2,3 and 4 respectively.

Table No. 1: Data and results of parental attitude on the employability of their hearing impaired children

\begin{tabular}{|c|l|l|l|l|l|}
\hline Statement No. & $\begin{array}{l}\text { Strongly Agree } \\
(\mathrm{SA})\end{array}$ & Agree (A) & $\begin{array}{l}\text { Undecided } \\
(\mathrm{U})\end{array}$ & $\begin{array}{l}\text { Disagree } \\
(\mathrm{D})\end{array}$ & $\begin{array}{l}\text { Strongly } \\
\text { Disagree (SD) }\end{array}$ \\
\hline 1 & $79(65.83 \%)$ & $40(33.33 \%)$ & $1(0.83 \%)$ & 0 & 0 \\
\hline 2 & $51(42.5 \%)$ & $62(51.66 \%)$ & $6(5 \%)$ & 0 & $1(0.83 \%)$ \\
\hline 3 & $7(5.83 \%)$ & $18(15 \%)$ & $29(24.16 \%)$ & $46(38.33 \%)$ & $20(16.66 \%)$ \\
\hline 4 & $20(16.66 \%)$ & $41(34.16 \%)$ & $34(28.33 \%)$ & $20(16.66 \%)$ & $5(4.16 \%)$ \\
\hline 5 & $9(7.5 \%)$ & $11(9.16 \%)$ & $14(11.66 \%)$ & $63(52.5 \%)$ & $23(19.16 \%)$ \\
\hline 6 & $3(2.5 \%)$ & $16(13.33 \%)$ & $44(36.66 \%)$ & $44(36.66 \%)$ & $10(10.83 \%)$ \\
\hline
\end{tabular}

From the above table it is seen that the parental community as a whole have strong agreement towards supported competitive employment for their hearing impaired children. The situation is seen in favour of $99 \%$ of parental population to the item that the hearing impaired child is capable of doing jobs with sufficient support from the society. Again the parental community is of the opinion that there is room for anxiety or concern. Since the child is under the supervision of a trained personnel in matter of job. This is a welcome note since parents are satisfied with the supervision of trained personnel under whose guidance their children are to undergo vocational training.

At the same time, the parental community had expressed their concern that their children are not in a secure position even though these children are given enough support to enter into a vocation in the society $(55 \%)$. At the same time it is be noted that about $24.16 \%$ of parents are uncertain/undecided on the matter of safety/security of their children for supported competitive employment in the society. The parents are confident that their hearing impaired children are capable of a vocation without a help from others (51\%). The undecided factor being $28.33 \%$.

Even though the parental community expressed confidence of their children capable of a vocation independent of their own, they put it emphatically that expert support from a trained person is essential which was expressed through the $5^{\text {th }}$ item in the table $(71 \%)$. This is to be specially noted, though these children will get support from their parents and siblings the expert help and assistance from trained personnel is found to be more appreciable to the parent community.

It is again revealed from the table that parents are hopeful of supported competitive employment of their hearing impaired children (47\%). At the same time the undecided/uncertain factor being $36.66 \%$ the direction being in favour of supported competitive employment.

Table 2: Data and results of parent's attitude on placing children in the existing jobs in the community

\begin{tabular}{|c|l|l|l|l|l|}
\hline Statement No. & Strongly Agree & Agree & Undecided & Disagree & Strongly Disagree \\
\hline 7 & $45(37.5 \%)$ & $64(53.33 \%)$ & $5(4.16 \%)$ & $5(4.16 \%)$ & $1(0.83 \%)$ \\
\hline 8 & $56(46.66 \%)$ & $52(43.33 \%)$ & $11(9.16 \%)$ & $1(0.83 \%)$ & 0 \\
\hline 9 & $4(3.33 \%)$ & $6(5 \%)$ & $32(26.66 \%)$ & $47(39.16 \%)$ & $31(24.83 \%)$ \\
\hline
\end{tabular}

From the above data, it is clear that parents are interested in sending their children to any type of vocation that are available in the society if there is support from experts (9.66\%). Parents again expressed that 
their hearing impaired children when send for a vocation will be benefitted for themselves as well as the society $(64 \%)$.

Table 3: Data and results of parent's willingness to send their children for different existing job in the community

\begin{tabular}{|l|l|l|l|l|l|}
\hline Jobs & SA & A & U & D & SD \\
\hline Envelop making & $41(34.6 \%)$ & $16(13.33 \%)$ & $58(48.37 \%)$ & $5(4.16 \%)$ & 0 \\
\hline Computer field & $55(45.83 \%)$ & $20(16.66 \%)$ & $44(36.66 \%)$ & $1(0.83 \%)$ & 0 \\
\hline Book binding & $45(37.5 \%)$ & $18(15 \%)$ & $54(45 \%)$ & $3(2.5 \%)$ & 0 \\
\hline Clerical jobs & $48(40 \%)$ & $15(12.5 \%)$ & $57(47.5 \%)$ & 0 & 0 \\
\hline Office file making & $37(30.83 \%)$ & $16(13.33 \%)$ & $63(52.5 \%)$ & $3(2.5 \%)$ & $1(0.83 \%)$ \\
\hline Printing works & $36(30 \%)$ & $13(10.83 \%)$ & $65(54.16 \%)$ & $5(4.16 \%)$ & $1(0.83 \%)$ \\
\hline Peon jobs & $38(31.66 \%)$ & $10(8.33 \%)$ & $64(53.33 \%)$ & $5(4.16 \%)$ & $3(2.5 \%)$ \\
\hline Tailoring & $35(29.16 \%)$ & $14(11.66 \%)$ & $66(55 \%)$ & $4(3.33 \%)$ & $1(0.83 \%)$ \\
\hline Agricultural jobs & $27(22.5 \%)$ & $14(11.66 \%)$ & $72(60 \%)$ & $6(5 \%)$ & $1(0.83 \%)$ \\
\hline Hospital jobs & $27(22.5 \%)$ & $15(12.5 \%)$ & $70(58.33 \%)$ & $8(6.66 \%)$ & 0 \\
\hline Jobs related to Fisheries & $16(13.33 \%)$ & $14(11.66 \%)$ & $79(65.83 \%)$ & $9(7.5 \%)$ & $2(1.6 \%)$ \\
\hline Poultry & $22(18.33 \%)$ & $12(10 \%)$ & $77(64.16 \%)$ & $6(5 \%)$ & $3(2.5 \%)$ \\
\hline
\end{tabular}

The analysis of responses received from the parental community emphatically proved that a vast majority of parental population are either unaware or uncertain of the pros and cons of the various vocations. $90 \%$ of the parental community expressed their willingness in favour of clerical jobs.47.49\% of the parents are in favour of envelop making. Majority of parents $(62.49 \%)$ are willing to send their children to computer fields.52.5\% parents are willing to send their children to do book binding. But $25 \%$ parents are agreed to send their children to job related to fisheriesand $28 \%$ parents are willing to send their children to poultry.

Table 4: Data and result of the extent of parental support to be extended to Childs employment

\begin{tabular}{|c|l|l|l|l|l|}
\hline $\begin{array}{c}\text { Statement } \\
\text { No. }\end{array}$ & \multicolumn{1}{|c|}{ SA } & \multicolumn{1}{|c|}{ A } & \multicolumn{1}{|c|}{ U } & D & \multicolumn{1}{|c|}{ SD } \\
\hline 1 & $5(4.16 \%)$ & $10(8.38 \%)$ & $10(8.33 \%)$ & $72(60 \%)$ & $23(19.16 \%)$ \\
\hline 2 & $44(36.66 \%)$ & $69(57.5 \%)$ & $4(3.33 \%)$ & $3(2.5 \%)$ & 0 \\
\hline 3 & $9(7.5 \%)$ & $17(14.16 \%)$ & $7(5.83 \%)$ & $66(55 \%)$ & $21(17.5 \%)$ \\
\hline
\end{tabular}

The above data reveals the extent of support the parental community is ready to provide in the vocational placement of the hearing impaired children. Majority of parents $(94 \%)$ had expressed their willingness to associate with the specialized trained personnel. Parents (73\%) are also ready to pay personnel attention to the hearing impaired children even though they are engaged in other responsibilities.

\section{Conclusions}

The parental communities as a whole have strong agreement towards supported competitive employment for their hearing impaired children (99\%). Parents are hopeful of supported competitive employment (47\%), but at the same time the undecided/uncertain factor being $36.66 \%$ the direction being in favour of supported competitive employment. Parents indicates positive attitude in placing their children in the existing jobs in the community (90\%). More than $90 \%$ of the parental community expressed their willingness in favour of clerical jobs. A vast majority of the parental community $(80 \%)$ had expressed their willingness to associate with specialized trained personnel in the employment of their hearing impaired children. In general parental community as a whole is ready to extend all forms of help and facilities to the specialized trained personnel out of their earnest desire for the right vocational placement of their children.

\section{Implications}

Parents welcome the idea of support being extended to the hearing impaired children by employment specialist in getting adequate professional support at workplace. They hopefully believe that community will tolerate and show patience towards the mistakes and disorders that may be committed by the child at work. Parents are willing to provide necessary arrangements to the job trainer and cooperate with the employer. So the non-governmental organizations as well as such other organizations should take earnest effort to extend supported competitive employment for the hearing impaired children, so that children are also brought to the main stream of the society.

\section{References}

[1]. Anju, Sikk. et al. (1990). Improving and expanding social interaction skills in supported employment settings. U.S. Mississippi.

[2]. Egelston, Doddy. (1988). Vocational Rehabilitation Training. Council of state administrators of vocational rehabilitation, Washington.

[3]. Sadoski. (1978). Library training institute for service to the deaf. California State University.

[4]. Kay, H., Lam. (1994). Young deaf adults and the transition from high school to post secondary careers. Gallaudet research institute, Washington. 
[5]. Parasmis. Etal. (1996). Attitude of teachers and parents in India toward career choices for deaf and hearing people. American Annals of the Deaf, 141, 303-08.

[6]. Ross, Gaylord. (1991). Supported employment for youth who are deaf-blind and in transition. Career Development for Exceptional Individuals, $14,77-89$.

[7]. Havalappanavar, N. B. (2001). Vocational interests of professional and non-professional college students. Journal of Psychological Researches, 45(1), 9-14.

[8]. Barnett, S., \& Franks, P. (1999). Telephone ownership and deaf people: Implications for telephone surveys. American Journal of Public Health, 89 (11), 1754-1756.

Parental attitude scale on supported competitive employment for their hearing impaired children

\section{$\underline{\text { Personal information about the child }}$}

1. Name of the child

2. Age

3. Male/Female

4. Religion

5. Residence, Rural/urban

6. Years of schooling

7. Guardian's Name

8. Relationship with child

9. Address

Information about family members

\begin{tabular}{|c|l|l|l|l|l|}
\hline No. & \multicolumn{1}{|c|}{$\begin{array}{c}\text { Relationship with the } \\
\text { child }\end{array}$} & Age & $\begin{array}{c}\text { Educational } \\
\text { qualification }\end{array}$ & Occupation & $\begin{array}{c}\text { Monthly } \\
\text { income }\end{array}$ \\
\hline 1 & Father & & & & \\
2 & Mother & & & & \\
\hline 3 & Brothers & & & & \\
\hline & Others & & & & \\
\hline
\end{tabular}


In the following statements the word community denotes job with normal persons. Read the statement and respond with ' $\sqrt{ }$ ' mark.

\begin{tabular}{|c|c|c|c|c|c|c|}
\hline $\begin{array}{l}\text { Sl. } \\
\text { No. }\end{array}$ & I & 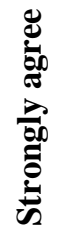 & 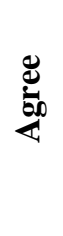 & 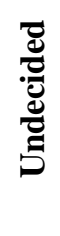 & 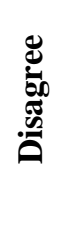 & 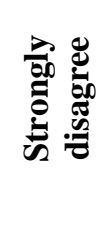 \\
\hline 1 & $\begin{array}{l}\text { Being able to work in the community with adequate } \\
\text { supports is very good for my child }\end{array}$ & & & & & \\
\hline 2 & $\begin{array}{l}\text { Since there is the supervision of supported } \\
\text { employment specialist, parents need not worry about } \\
\text { the child during work. }\end{array}$ & & & & & \\
\hline 3 & $\begin{array}{l}\text { Though there is the support of employment specialist, } \\
\text { working in the community is not safe for my child. }\end{array}$ & & & & & \\
\hline 4 & $\begin{array}{l}\text { My child is capable of working in the community } \\
\text { without the support of others. }\end{array}$ & & & & & \\
\hline 5 & $\begin{array}{l}\text { Child does not need the help of the specialist as he/she } \\
\text { has support of parents and siblings in the employment }\end{array}$ & & & & & \\
\hline 6 & $\begin{array}{l}\text { I don't expect that the child will get needed } \\
\text { professional support for working successfully }\end{array}$ & & & & & \\
\hline
\end{tabular}

In the following statements the word community denotes job with normal persons. Read the statement and respond with ' $\sqrt{ }$ ' mark.

\begin{tabular}{|c|c|c|c|c|c|c|}
\hline $\begin{array}{l}\text { Sl. } \\
\text { No. }\end{array}$ & II & 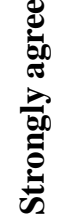 & 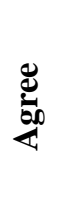 & 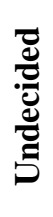 & 总 & 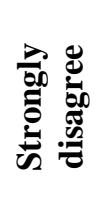 \\
\hline 7 & $\begin{array}{l}\text { There are various job opportunities in our society in which } \\
\text { hearing impaired children can successfully engage }\end{array}$ & & & & & \\
\hline & $\begin{array}{l}\text { Some of the jobs available in the society are given below. } \\
\text { Which of them would you prefer for your child } \\
\text { a. Envelop making } \\
\text { b. Computer } \\
\text { c. Book binding } \\
\text { d. Clerical jobs } \\
\text { e. Office file making }\end{array}$ & & & & & \\
\hline
\end{tabular}




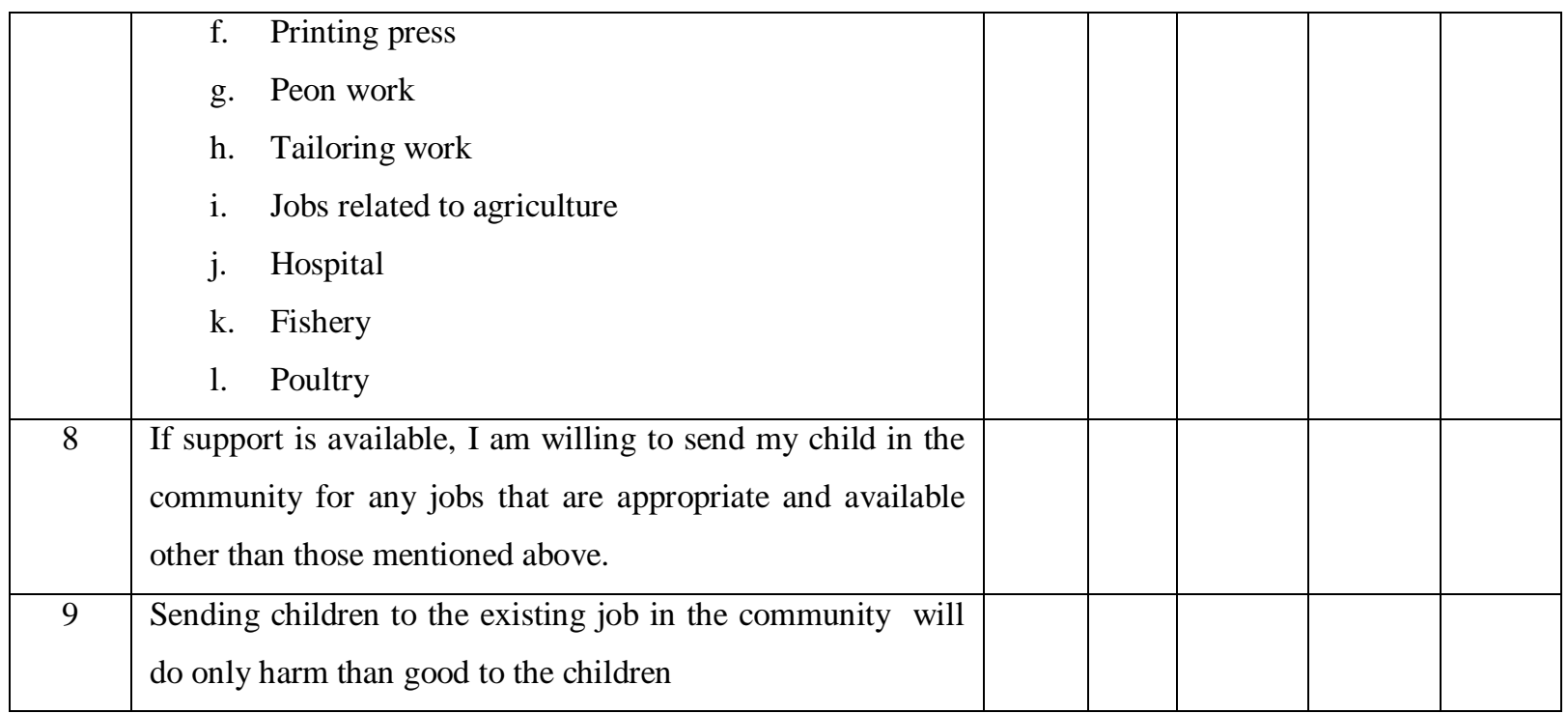

In the following statements the word community denotes job with normal persons. Read the statement and respond with ' $\sqrt{ }$ ' mark.

\begin{tabular}{|c|c|c|c|c|c|c|}
\hline $\begin{array}{l}\text { Sl. } \\
\text { No. }\end{array}$ & III & 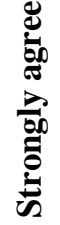 & 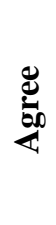 & 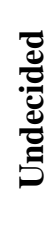 & 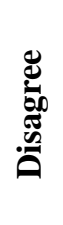 & 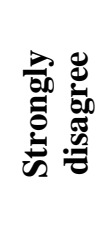 \\
\hline 1 & $\begin{array}{l}\text { As supported employment specialist is a qualified } \\
\text { person, I need not co operate with him }\end{array}$ & & & & & \\
\hline 2 & $\begin{array}{l}\text { I will provide necessary arrangements to the job } \\
\text { trainee for imparting training to the child in the } \\
\text { available jobs in the community }\end{array}$ & & & & & \\
\hline 3 & $\begin{array}{l}\text { Since I have other responsibilities at home, I will not } \\
\text { be able to attend child's related affairs }\end{array}$ & & & & & \\
\hline
\end{tabular}

